\title{
The Effect of Edu-RJP on Knowledge of Cardiopulmonary Resuscitation in Nursing Students at STIKES Panakkukang Makassar
}

St Nurhazana S, Muh Zukri Malik*, I Kade Wijaya, and Makkasau Makkasau

STIKES Panakkukang Makassar

\section{ORCID}

Muh Zukri Malik: https://orcid.org/0000-0002-1472-0020

Corresponding Author: Muh Zukri Malik; email:

zukrimalik@gmail.com

Published: 7 February 2022

Publishing services provided by Knowledge E

(c) St Nurhazana S et al. This article is distributed under the terms of the Creative Commons Attribution License, which permits unrestricted use and redistribution provided that the original author and source are credited.

Selection and Peer-review under the responsibility of the IVCN Conference Committee.

\section{G OPEN ACCESS}

\begin{abstract}
Cardiac arrest is the leading cause of medical emergency of the cardiovascular system. The most effective management is immediate cardiopulmonary resuscitation (CPR). The most influential factor for whether CPR is successful is the level of knowledge. An Android application can be an effective way to enhance knowledge related to CPR. The objective of this research was to determine the effect of the Edu-RJP application on the knowledge related to CPR in the nursing students of STIKES Panakkukang Makassar. The study employed a quasi-experimental pretest-posttest design with a control group. The participants were selected by using purposive sampling and the 40 respondents were divided into the experimental and control groups. The research instruments used were the Edu-RJP application, leaflets and questionnaires. CPR knowledge was compared before vs. after the nursing students used the Edu-RJP application or leaflets by independent $t$ test. The analysis showed that the Edu-RJP application had a significantly larger effect on the knowledge of CPR, compared to the leaflets. Thus, it seems that the more sophisticated the technology of learning media, the more influential it is in enhancing the knowledge of the nursing students.
\end{abstract}

Keywords: cardiopulmonary resuscitation, Edu-RJP, knowledge

\section{Introduction}

Cardiac arrest is the leading cause of medical emergency cases in the cardiovascular system [1]. Cardiac arrest can cause sudden death in a person if the heart's electrical system does not function and produces abnormal rhythms. The time of a person's occurrence when experiencing cardiac arrest can not be predicted with certainty, because the occurrence is very fast once the symptoms appear.

The most appropriate management of this condition is cardiopulmonary resuscitation (CPR) which aims to restore blood circulation throughout the body and prevent organ failure, especially the brain. The first few minutes in cardiac arrest cases are a golden period in increasing the success of CPR. Based on AHA 2015, the earlier the CPR action is carried out, the higher the success rate of cardiac arrest treatment [2]. 
Good CPR quality is affected by certain factors. One of them is knowledge. High levels of knowledge effectively aid successful resuscitation in preventing disability or death. [3]. Efforts to achieve good resuscitation skills, it requires good understanding and knowledge also by medical personnel or nonmedical personnel who will take action. This is useful to reduce the adverse impact or severity of symptoms of the remaining cardiac arrest patients so as to provide a better prognosis in patients.

Based on a survey conducted on May 2, 2021 with 34 nursing students of STIKES Panakkukang Makassar class of 2017, 2018, 2019, and 2020 who are willing to be the object of preliminary study obtained. The level of knowledge of students is still categorized low.

Lack of knowledge of nursing students in understanding cardiopulmonary resuscitation techniques because it is difficult to understand material related to CPR. The students are accustomed to reading books, but it would be better when using application simulations.

There are as many as $47.1 \%$ said one of the factors students lack understanding CPR material is the learning media used and $44.1 \%$ of percent said it is difficult to understand the material because of the absence of motivation to learn. In addition, researchers conducted a survey of effective learning methods used to study cardiopulmonary resuscitation materials from 34 respondents as many as 70.6 percent chose an effective android application used as a learning medium for cardiopulmonary resuscitation material.

Along with the rapid development of digital technology. Technology can be used by the public in making it easier to perform any task and work [4]. Android application as one of the media that is considered effective in the learning process, because it can increase interest and motivation more learners in learning and learning activities [5].

Based on Masriami's research [6] which developed the MABAR application in measuring the level of self-efficacy of Senior High School Students 8 Malang City in the management of CPR gained significant influence on self-efficacy variables after using the MABAR application. This is what makes researchers plan to develop an androidbased application innovation called EDU-RJP to support cardiopulmonary resuscitation learning.

The fundamental difference between the application developed by Masriami (2018) with the EDU-RJP researcher application is the design and creation of edu-RJP application using Java Development Kit and Website APK 2 Builder so that the application capacity is lighter in student mobile phones. Edu-RJP applications are made with costum shades of black and attractive. Edu-RJP application features are equipped with 
introductory video at the beginning when opening the application, then equipped with interesting virtual modules, along with simulations and guided by the latest guidelines AHA. In addition, the focus of research in EDU-RJP is to increase the knowledge and understanding of nursing students in pulmonary cardiac resuscitation.

EDU-RJP stands for cardiopulmonary resuscitation education which is an android application designed using Java Development Kit and Website APK 2 Builder so that it can be accessed on student mobile phones. Edu-RJP application features are equipped with introductory video at the beginning when opening the application, then equipped with virtual modules, videos, simulations, and quizzes guided by the AHA 2015 guideline.

General purpose of research: the known effect of EDU-RJP on CPR knowledge in STIKES Panakkukang Makassar nursing students, while the specific purpose of this study is the identification of CPR knowledge in Nursing undergraduate students before and after using Edu-RJP application and Leaflet, and the analysis of comparison of CPR knowledge differences after using Edu-RJP and Leaflet.

\section{Method}

The research design used in this study is Quasi Experimental Research with a pre-test approach and post test control group design.

The target population in this study is all active students of S1 Nursing regular STIKES Panakkukang Makassar which is 153 students.

The sample used in this study was 40 regular Nursing Undergraduate students 2019 at STIKES Panakkukang Makassar which were divided into 2 groups, namely the experimental group (Edu-RJP) and the control group (Leaflet).

Sampling in this study used non probability sampling with purposive sampling that met the criteria of inclusion and exclusion.

Inclusion criteria: (1) Active Students; (2) Male and female sex; (3) Have never attended CPR training before; (4) Willing to follow the activities until completion; (5) Respondents own a smartphone; (6) Willing to install Edu-RJP application on smartphone.

While the student exclusion criteria that do not allow running Edu-RJP application.

The independent variables in the study were Edu-RJP and leaflet application media, while the dependent variables in the study were nursing students' knowledge of RJP.

For research instruments used are Edu-RJP Applications, Leaflets, and questionnaires. 
TABLE 1: Frequency Distribution of Knowledge Level of Cardiopulmonary Resuscitation Media Edu-RJP Application and Leaflets

\begin{tabular}{|c|c|c|c|c|c|c|c|c|}
\hline \multirow[t]{3}{*}{ Category } & \multicolumn{4}{|c|}{ Edu-RJP Group } & \multicolumn{4}{|c|}{ Leaflets Group } \\
\hline & \multicolumn{2}{|c|}{ Pre test } & \multicolumn{2}{|c|}{ Post test } & \multicolumn{2}{|c|}{ Pre test } & \multicolumn{2}{|c|}{ Post test } \\
\hline & $n$ & $\%$ & $n$ & $\%$ & $n$ & $\%$ & $n$ & $\%$ \\
\hline Good & 4 & 20 & 8 & 40 & 1 & 5 & 1 & 5 \\
\hline Enough & 2 & 10 & 10 & 50 & 2 & 10 & 6 & 30 \\
\hline Less & 14 & 70 & 2 & 10 & 17 & 85 & 13 & 65 \\
\hline
\end{tabular}

The following is the technique of conducting research in the Edu-RJP group: (1) The first day, the Researcher provides an explanation of the research, then the respondent fills out the approval sheet through google form; (2) Pretesting using google form; (3) Download of Edu-RJP application by respondents; (4) RJP learning by using Edu-RJP android application media; (5) Given 3 days to be in the use and understanding of RJP learning; (6) The Researcher controls respondents who have difficulty during the use of the application; (7) After 3 days ended with posttest; (8) The data analysis is carried out.

As for the technique of conducting research in the Leaflet group: (1) The first day, the Researcher provides an explanation of the research, then the respondent fills out the approval sheet through google form; (2) Pretesting using google form; (3) Send leaflets in image format via whatsapp; (4) RJP learning using leaflet media. (5) Given 3 days to be in the use and understanding of RJP learning; (6) The researcher controls respondents who have difficulty during learning, (7) After 3 days ended with posttest; (8) The data analysis is carried out. The data analysis technique used is the t-test.

\section{Result}

\subsection{Student Knowledge Results on Cardiopulmonary Resuscitation Using Edu-RJP Group and Leaflet Group}

Based on the table above it is known that before being given edu-RJP application the majority of students have less knowledge of $70 \%$ and after being given edu-RJP application becomes sufficient by $50 \%$. While in the leaflet group before being given the majority of knowledgeable leaflets less by $85 \%$ and after being given the student leaflet is still less at $65 \%$. 
TABLE 2: Data Results Pretest and Posttest Edu-RJP Group and Leaflet Group

Pretest Edu-RJP
Posttest Edu-RJP
Pretest Leaflet
Posttest Leaflet

$\mathbf{N}$
20
20
20
20

Mean
49,25
70,25
45,50
54,75

Std. Deviation

17,112

13,126

16,051

${ }^{*}$ Test Descriptive Statistics Pretest Value and Posttest Edu-RJP Groups and Leaflets

TABLE 3: Difference in Knowledge Score Before and After Learning Using Edu-RJP Application

\begin{tabular}{l|lll} 
Group & \multicolumn{2}{c}{ Mean } & Sig \\
\cline { 2 - 3 } & Pre test & Post test & \\
Edu-RJP & 49,25 & 70,25 & 0,000 \\
\hline Leaflet & 45,50 & 54,75 & 0,012 \\
\hline *Paired T-Test $\mathrm{p}<0.05$ shows there is a significant difference. &
\end{tabular}

\subsection{Differences in Knowledge Before and After Learning Cardiopulmonary Resuscitation Using Edu-RJP}

After the normality test, the data obtained is normal distribution with a signification value (sig) that is a sig value $>0.05$. The value of significance (sig) $=0.208$ means sig $>0.05$ can be concluded that both groups are homogeneous. Next, the Paired T Test analysis was conducted.

Based on the table shows the signification value of 0.000 , which means that it can be known that the value $p<0.05$ so that it is concluded that there is a difference in knowledge scores before and after using the Edu-RJP application.

Based on table 7 shows the signification value of 0.012 which means it can be known that the value $p<0.05$ so that it is concluded that there is a difference in knowledge scores before and after using leaflets.

TABLE 4: Differences in Cardiaopulmonary Resuscitation Knowledge Results After Using Edu-RJP and Leaflets

\begin{tabular}{l|l|l|l}
\hline Difference in knowledge & $\mathbf{n}$ & P Value & Mean Difference \\
\hline Edu-RJP & 20 & 0,000 & 15,500 \\
\hline Leaflet & 20 & 0,000 & 15,500 \\
\hline *Independent Simple T-Test & & &
\end{tabular}




\subsection{Differences in Cardiopulmonary Resuscitation Knowledge Results After Using Edu-RJP and Leaflet}

Based on the Independent t-test, the average difference value in the Edu-RJP application group and leaflet was 15,500. The results of the analysis showed a $p$ value of 0.000 which means that there is a difference in CPR knowledge using Edu-RJP and Leaflet applications.

\section{Discussion}

\subsection{Knowledge of cardiopulmonary resuscitation of Nursing under- graduate students before and after using Edu-RJP}

Based on the results of statistical tests using paired t-test tests on pulmonary cardiac resuscitation knowledge variables in RJP learning using edu-RJP applications obtained an average value after learning using edu-RJP application which is 70.25. While the average score before respondents were given cardiac resuscitation learning using eduRJP application was obtained at 49.25. The results showed that there was an increase in the average value before and after using the Edu-RJP application by 21 .

From the test, the average posttest value is greater than the pretest value where the difference in value shows an increase in knowledge in respondents after learning using Edu-RJP and the significance value obtained in the pretest and postest of pulmonary cardiac resuscitation knowledge is 0.000 where the value of sig $<0.05$ which means there is a significant difference in the knowledge variable before and after RJP learning by using Edu-RJP will be applied.

According to Rahmadi, et al [7] explained that in the teaching and learning process, learning media has a very important role because it is able to facilitate students in understanding a subject matter, especially material that is difficult for students to digest and abstract such as health sciences. Android smartphones are one of the alternative media in learning about skills because it can display text, images, and videos) so that the learning process is more interesting and not monotonous.

Edu-RJP application developed by this researcher has the same characteristics as the research. Edu-RJP application that features applications in the form of virtual modules, simulations, videos, and quizzes that are easily accessible to respondents. This feature will help and attract respondents to do learning independently so as to increase student learning motivation in learning pulmonary heart resuscitation. 
Based on the results described above it can be known that the influence of EduRJP application on pulmonary heart resuscitation knowledge in respondents can have a significant influence on the increase in the value of one's knowledge in performing pulmonary heart resuscitation.

\subsection{Knowledge of cardiopulmonary resuscitation of Nursing undergraduate students before and after using leaflets}

Based on the results of statistical tests using paired t-tests on pulmonary heart resuscitation knowledge variables in RJP learning using leaflets obtained an average value after learning using leaflets which is 45.50 . While the average score before respondents were given cardiac resuscitation learning using edu-RJP application was obtained which is 54.75. The results showed that there was an increase in the average value before and after using the leaflet which was 9.25.

From the test obtained an average posttest value greater than the pretest value where the difference in value indicates an increase in knowledge in respondents after participating in learning using leaflets. While the significance obtained in the pretest and postest knowledge of pulmonary cardiac resuscitation is 0.000 where the value of sig $<0.05$ which means there is a significant difference in the knowledge variable before and after RJP learning using leaflets.

According to Sarwono [8] explained the selection of leaflet media to convey information that can have a meaningful effect on improving one's knowledge and abilities through individual learning or instruction practice techniques such as using leaflet media.

The media leaflet used in this study was sourced from the Ministry of Health of the Republic of Indonesia. The leaflet consists of a number of words and images with an attractive color arrangement. Based on this, the leaflet media is effective in learning pulmonary cardiac resuscitation.

\subsection{Influence of comparative analysis of knowledge differences after learning using Edu-RJP and Leaflet applications}

In the hypothesis test students are pretested first, then after getting treatment using the Edu-RJP application, students are given a posttest to find out whether there is an influence or not after treatment. In tests used in pretest and posttest is a matter of right or wrong which amounts to 20 questions. Before the hypothesis test, the prerequisite 
test is carried out first. The prerequisite test in question is the normality test and the homogeneity test.

Based on the analysis of data from the experimental and control groups that have been carried out, for the normality test obtained a siginification value of more than 0.05 so that it is concluded that the data obtained is normal distribution. For the homogeneity test, the result is 0.208 where the significance value is greater than 0.5 so it is concluded that the pretest and posttest values have homogeneous variants. So that the prerequisite test is met then continued with the $t$ test.

Based on the analysis of data from the experimental and control groups that have been carried out, for the normality test obtained a siginification value of more than 0.05 so that it is concluded that the data obtained is normal distribution. For the homogeneity test, the result is 0.208 where the significance value is greater than 0.5 so it is concluded that the pretest and posttest values have homogeneous variants. So that the prerequisite test is met then continued with the $t$ test.

The results of the independent t-test of knowledge of pulmonary cardiac resuscitation after being given treatment in the Edu-RJP group and leaflets found that there was a significant difference in the knowledge value of edu-RJP group and leaflet after being treated.

Edu-RJP's influence on student knowledge results that there are meaningful differences before and after using the application. In hypothesis testing, the data showed that the significance value (2-tailed) $<0.05$ which is $0.000<0.05$ then $\mathrm{HO}$ rejected $\mathrm{H} 1$ was accepted, meaning there was a significant influence of Edu-RJP application on the knowledge of pulmonary cardiac resuscitation of nursing students at STIKES Panakkukang Makassar. This is because the Edu-RJP application can make students better understand the concept in depth because smartphones are an easy, efficient, and usable medium anywhere, as well as application features that support students' motivation and interest in learning pulmonary heart resuscitation.

According to Nurcahyo [9] explained the effectiveness of android application learning media can be reviewed from the criteria of effectiveness in learning The magnitude of the influence of the use of android application learning media can be known by looking for the difference between the average posttest value of the control class and the experimental class.

From the data above it can be known that the more sophisticated the technology of pulmonary heart resuscitation learning media used, the higher the influence in increasing lung heart resuscitation knowledge in undergraduate nursing students so that it can be concluded that the learning process using android application learning 
media is more effectively applied in the learning process because edu-RJP application has a major influence on the knowledge of pulmonary heart resuscitation of students nursing at STIKES Panakkukang Makassar.

The implications of nursing are theoretical implications, namely Edu-RJP can be one of the CPR learning media in emergency courses while the practical implication is Edu-RJP can be a public media for nurses to use as an educator in providing health promotion.

While the limitations in this study are: 1) The material taught still uses the American Heart Association (AHA) 2015; 2) Not appropriate implementation of research with the matrix of research plans, because respondents are constrained by poor internet network; 3) Lack of application of learning media in increasing student knowledge; 4) There are many other factors that affect student knowledge outcomes; 5) Variations in posttest problems are considered less because the material used for posttest is already used for pretest; 6) The existence of pretest first before treatment is suspected to be an influence on posttest results, 7) Supervision of the use of Edu-RJP android application is considered still lacking because it is controlled only limited to virtual.

\section{Conclusion}

Based on the results of the study, knowledge of cardiopulmonary resuscitation of students before and after using Edu-RJP applications increased by 21 where the average value before and after using Edu-RJP applications was 49.25 and 70.25, so it was concluded that there was a significant influence on knowledge variables before and after learning cardiac resuscitation using Edu-RJP applications.

Based on the results of the study, knowledge of cardiopulmonary resuscitation of students before and after using leaflets increased by 9.25 where the average value before and after using leaflets was 45.50 and 54.75 , so it was concluded that there was a significant influence on knowledge variables before and after learning heart resuscitation using leaflet applications.

Based on the results of a comparative analysis of differences in heart resuscitation knowledge after being given edu-RJP application and leaflet using independent $\mathrm{t}$ test test found that the value of significance (2-tailed) $<0.05$ which is $0.000<0.05$ means that edu-RJP application has a significant influence on lung heart resuscitation knowledge compared to leaflets so that it is concluded that the more sophisticated the learning technology of pulmonary cardiac resuscitation used the higher the influence in increasing lung heart resuscitation knowledge in nursing undergraduate students. 
Based on the results of the study, the researcher provides advice to the next researchers as follows: 1) It is necessary to update the virtual modules in Edu-RJP applications in accordance with the latest guidelines; 2) It is necessary to add sound, music, or beats so that Edu-RJP application users can get maximum use; 3) The addition of new features that support the improvement of cardiopulmonary resuscitation knowledge in application users; 4) Data retrieval should be more so that the data obtained is more significant.

\section{References}

[1] Dan P, Anak S, Sekolah U. 2021;15(8):4993-5002.

[2] Herman A, Thalib S, Tk RS, Pelamonia II, Tenggara DA. Gambaran pengetahuan perawat tentang prosedur tindakan resusitasi jantung paru pada pasien. Jurnal Mitrasehat. 2006:62-73.

[3] Millizia A, Sawitri H, Harahap DA. Gambaran tingkat pengetahuan tenaga medis dan tenaga nonmedis tentang resusitasi jantung paru pada kegawatdaruratan di RSUD cut meutia aceh utara. Jurnal Kedokteran Nanggroe Medika.2020;3(3):1-10.

[4] Indonesia UP. Era digital dan tantangannya. 2017:1-9.

[5] Mubarok, I. W., \& Kartika, P. C. Efektifitas Penggunaan Bahan Ajar Berbasis Android Nemo Bahasa Indonesia untuk Mahasiswa BIPA Tingkat Pemula Program Darmasiswa Universitas Muhammadiyah Surabaya. Jurnal Pendidikan Bahasa dan Sastra Indonesia Metalingua. 2002:19-24.

[6] Rahmadi, Antun, Bertalina Ny, and Arie Nugroho. Pelatihan Aplikasi Gizi Berbasis Android Bagi Siswi Pionir Dalam Pencegahan Malnutrisi Di Sma Negeri 2 Tumi Jajar. Al-Mu'awanah: Jurnal Pengabdian Masyarakat 1.2 2020: 1-6.

[7] Pusparina, lis, Insana Maria, and Danti Tia Anggraini. Efektifitas Penggunaan Media Leaflet Terhadap Peningkatan Pengetahuan Tentang Narkoba Di Smpn 5 Banjarbaru. Jurnal Keperawatan Suaka Insan (JKSI) 4.2 (2019): 108-113.

[8] Fahmi, Nasrina Nur, and Slamet Slamet. Layanan Konseling Kelompok dalam Meningkatkan Rasa Percaya Diri Siswa SMK Negeri 1 Depok Sleman. Hisbah: Jurnal Bimbingan Konseling dan Dakwah Islam 13.2 (2016): 69-84. 